\title{
PENGARUH PERBEDAAN JENIS KAYU BAKAR DAN LAMA PENGASAPAN TERHADAP MUTU SENSORI IKAN PATIN ASAP (Pangasius pangasius)
}

\section{EFFECT OF DIFFERENT WOODS AND SMOKING DURATION ON THE QUALITY OF SMOKED PANGASIUS (Pangasius pangasius)}

\author{
Resmi R. Siregar ${ }^{1 \#}$, I Ketut Sumandiarsa ${ }^{1}$, dan Zulkhairina ${ }^{1}$ \\ ${ }^{1}$ Program Studi Teknologi Pengolahan Hasil Perikanan, Sekolah Tinggi Perikanan \\ Jl. AUP No. 1 Pasar Minggu, Jakarta Selatan \\ E-mail: resmi.siregar@gmail.com
}

(Diterima: 21 November 2019; Diterima setelah perbaikan: 2 Juni 2020; Disetujui: 2 Juni 2020)

\begin{abstract}
ABSTRAK
Lama pengasapan dan jenis kayu yang digunakan akan mempengaruhi mutu ikan asap yang dihasilkan, karena setiap jenis kayu mengandung senyawa kimia yang berbeda-beda. Penelitian ini bertujuan untuk mengetahui pengaruh perbedaan kayu bakar yang digunaan dan lama pengasapan terhadap mutu ikan patin asap. Ikan patin yang digunakan berukuran 200-300 gr/ekor. Pengujian yang dilakukan adalah uji hedonik (kesukaan) terhadap kenampakan, bau, rasa dan tekstur ikan patin asap. Penelitian menggunakan Rancangan Acak Kelompok (RAK) dengan perlakuan jenis kayu (kayu karet dan kayu rambutan) dan lama pengasapan (8 jam, 9 jam, dan 10 jam). Data yang diperoleh dianalisis dengan Kruskal Wallis. Dari hasil pengujian hedonik diketahui bahwa panelis lebih menyukai ikan patin yang diasap dengan kayu rambutan selama 9 jam. Uji statistik menunjukkan bahwa perbedaaan jenis kayu (kayu karet dan kayu rambutan) tidak berpengaruh nyata terhadap nilai hedonik ikan patin asap (Chi Square $=3,627$ dan $p$-value 0,057 $>0,05$ ), sedangkan lama pengasapan pada rentang waktu 8 jam, 9 jam dan 10 jam, berpengaruh nyata terhadap nilai hedonik ikan patin asap (Chi Square $=7,506$ dan $p$-value $0,023<0,05$ ).
\end{abstract}

KATA KUNCI: Kayu bakar; pengasapan; patin; mutu

\begin{abstract}
Duration of smoking and varied of woods as smoke source material will influence the quality of smoked fish, since different woods contains different chemical compounds. This research was aimed to determine the effect of different woods and smoking duration on the hedonic of smoked pangasius, include appereance, odor, flavor and texture. The research was used experimental Randomized Groups Design with two various woods include Hevea brasiliensis and Nephelium lappaceum L and 8 hours, 9 hours and 10 hours of smoking duration. The results were analyzed by Kruskal Wallis. Based on hedonic test, panelists more preferred smoked pangasius which was 9 hours of smoking with rambutan wood. The statistic test showed that the type of wood (Hevea brasiliensis and Nephelium lappaceum L) wasn't influence the consumer preferences of smoked pangasius, while smoking duration (8 hours, 9 hours and 10 hours) was influence consumer preferences of smoked pangasius (Chi Square $=7.506$ dan p-value $0.023<0.05$ ).
\end{abstract}

KEYWORDS: Wood; smoking; pangasius; quality

\section{PENDAHULUAN}

Ikan merupakan bahan pangan yang cepat mengalami proses pembusukan dibandingkan dengan

\footnotetext{
\# Korespondensi: Program Studi Teknologi Pengolahan Hasil Perikanan Sekolah Tinggi Perikanan

E-mail: resmi.siregar@gmail.com
}

bahan makanan lain (Mardiana et al., 2014), sehingga perlu dilakukan proses pengawetan dan pengolahan lebih lanjut. Salah satu metode pengolahan yang mempunyai ciri khas adalah pengasapan. Pengasapan merupakan suatu cara pengolahan atau pengawetan dengan memanfaatkan kombinasi perlakuan pengeringan dan pemberian senyawa kimia dari hasil 
pembakaran bahan bakar alami (Wibowo, 2002). Daya awet pada ikan asap timbul dari komponen asap karena adanya kandungan yang bersifat antimikrobial dan antioksidan yaitu senyawa aldehid, asam karboksilat dan fenol (Leroi \& Joffraud, 2000; Rorvik, 2000). Cara pengolahan dengan pengasapan telah dilakukan sejak dulu hingga kini, dengan tujuan untuk mengurangi kadar air dalam tubuh ikan serta membunuh atau menghambat pertumbuhan mikroba dengan bahan alami yang bersumber dari asap (Lambongadil et al., 2014).

Pengasapan ikan yang berkembang di Indonesia pada dasarnya ada dua metode yaitu pengasapan panas (hot smoking) dan pengasapan dingin (cold smoking). Pengasapan panas biasanya menggunakan suhu sekitar $70-80{ }^{\circ} \mathrm{C}$ selama $4-5 \mathrm{jam}$. Sedangkan pengasapan dingin biasanya menggunakan suhu sekitar $40-50{ }^{\circ} \mathrm{C}$ selama beberapa hari bahkan dapat mencapai beberapa minggu. Biasanya ikan asap dari proses pengasapan dingin memiliki daya simpan yang lebih lama bila dibandingkan dengan ikan asap yang dihasilkan dari pengasapan panas. Hal ini disebabkan perbedaan kadar air pada ikan asap tersebut yang dipengaruhi oleh perbedaan waktu pengasapan. Hal ini sesuai dengan Mardiana et al. (2014) bahwa kadar air ikan asap mengalami penurunan seiring dengan lama waktu pengasapan. Hal ini membuktikan bahwa waktu pengasapan yang dilakukan mempengaruhi komposisi kimia ikan asap serta mempengaruhi jumlah komponen asap yang diserap oleh ikan. Menurut Afrianto dan Liviawaty (1989) bahwa setiap jenis kayu mempunyai asap dengan kadar unsur kimia (air, aldehid, asam asetat, keton, alkohol, asam formiat, fenol, karbondioksida) yang berbeda, yang akan mempengaruhi daya awet ikan asap yang dihasilkan. Namun, perlu diketahui bahwa kandungan fenol yang terlalu tinggi pada ikan asap cenderung menimbulkan rasa pahit pada ikan asap bahkan dapat menghasilkan Polycyclic Aromatic Hydrocarbon (PAH) yang bersifat karsinogenik. Meskipun demikian, produk hasil pengasapan umumnya masih diminati oleh konsumen.

Penelitian terkait lama pengasapan dan jenis kayu yang berbeda telah banyak dilakukan. Ratna et al. (2011) menggunakan tempurung kelapa, sekam padi, sabut kelapa dan kayu dalam pengasapan ikan bandeng. Hadinoto et al. (2016) menggunakan asap cair tempurung kelapa untuk pengolahan ikan cakalang asap. Suroso et al. (2018) menggunakan asap cair dari kayu karet hasil redestilasi untuk pengasapan ikan kembung. Sejauh ini penelitian tentang penggunaan kayu karet dan kayu rambutan secara bersamaan dalam pengasapan ikan patin belum dilakukan.

Propinsi Riau merupakan daerah penghasil ikan asap khususnya Patin asap. Pada umumnya para pengolah menggunakan kayu rambutan dan kayu karet sebagai sumber asap, karena kedua jenis kayu tersebut tersedia cukup banyak yang berasal dari perkebunan karet maupun perkebunan rambutan setempat. Namun, sampai saat ini belum dilakukan kajian terkait karakteristik ikan asap yang dihasilkan dari proses pengasapan dengan kayu rambutan maupun kayu karet. Oleh karena itu, penelitian ini bertujuan untuk mengetahui pengaruh perbedaan jenis kayu bakar dan lama pengasapan terhadap nilai kesukaan panelis.

\section{BAHAN DAN METODE}

Bahan yang digunakan dalam proses pengolahan adalah ikan patin yang dibeli dalam kondisi hidup dengan ukuran 250-300 gr/ekor, air dan es, asam cuka (for food). Bahan baku berasal dari Bangkinang, Teratak Buluh, Batu Belah, Simpang Kubu, Tibun, Air Tiris, Perawang, dan Sungai Salak dalam keadaan hidup. Peralatan yang digunakan untuk pengolahan ikan asap adalah rumah pengasapan, ember, keranjang plastik, pisau, talenan dan timbangan (analytical balance kern) dan scoresheet organoleptic. Ikan asap diolah dengan tahapan sebagai berikut: penimbangan, penyiangan, pencucian, perendaman dengan larutan cuka 3\% selama 15 menit, penirisan, pengasapan dengan kayu rambutan dan kayu karet selama 8 jam, 9 jam dan 10 jam dengan suhu $75-90{ }^{\circ} \mathrm{C}$, pendinginan dan pengemasan (SNI 2725:2013 dimodifikasi).

Metode penelitian yang dilakukan adalah eksperimen lapangan. Eksperimen lapangan adalah kajian penelitian dalam situasi nyata dengan memanipulasikan satu atau lebih variabel bebas oleh peneliti dalam kondisi apabila situasi memungkinkan (Kerlinger, 1986). Penelitian ini dilakukan untuk melihat pengaruh jenis kayu (kayu karet dan kayu rambutan) dan lama pengasapan (8 jam, 9 jam dan 10 jam), terhadap nilai kesukaan panelis. Uji hedonik atau uji kesukaan dilakukan untuk mengetahui penilaian panelis terhadap ikan asap yang dihasilkan pada setiap perlakukan. Skala hedonik yang digunakan berkisar 19 di mana (1) sangat tidak suka; (3) tidak suka; (5) netral; (7) suka; (9) sangat suka. Pengujian ini dilakukan sebanyak 3 kali pengamatan oleh 30 orang panelis. Data dianalisis dengan diolah menggunakan uji Kruskal Wallis, menggunakan model rancangan percobaan acak lengkap (RAL) yang disusun secara faktorial dengan dua faktor, yaitu jenis kayu dan lama pengasapan, dengan masing-masing tiga kali pengulangan, serta menggunakan uji lanjut Tukey.

\section{HASIL DAN BAHASAN}

\section{Pengolahan ikan patin asap}

Pengolahan ikan patin asap yang dilakukan meliputi: penerimaan bahan baku, penyiangan, pencucian, 
penyusunan, pengasapan, pendinginan, pengemasan, dan distribusi, mengacu pada SNI 2725:2013 tentang pengolahan ikan asap. Penyiangan diawali dengan mematikan ikan patin dan membelah bagian atas kepala hingga ke bagian punggung belakang (bentuk butterfly) serta dilakukan pengambilan isi perut. Proses penyiangan ini bertujuan untuk mereduksi bakteri pada ikan dengan membuang bagian yang tidak diperlukan seperti isi perut, insang dan lendir di permukaan tubuh ikan. Menurut Muchtadi dan Sugiyono (1992), pusat konsentrasi bakteri terletak pada bagian insang, kulit dan isi perut. Apabila tidak dilakukan penyiangan, bakteri akan berkembang biak dan akan menguraikan komponen-komponen daging yang menyebabkan terjadinya proses pembusukan. Pencucian dilakukan dengan menyikat bagian perut ikan, membilas darah dan kotoran yang masih menempel pada ikan dengan air bersih yang mengalir. Selanjutnya ikan direndam dengan larutan cuka (asam asetat) 3\% selama 15 menit. Perendaman dalam larutan cuka bertujuan untuk menghilangkan darah, lendir, dan memberikan cita rasa pada ikan asap. Asam cuka mengandung senyawa yang dapat memberikan cita rasa yang baik, sehingga penggunaan asam cuka lebih baik dari pada asam asetat murni (Suprayitno, 2017). Penyusunan ikan pada parapara pengasapan dilakukan sedemikian rupa sehingga berselang seling antara kepala dan ekor. Hal ini dilakukan agar semua bagian ikan mendapatkan aliran asap dan panas yang sama. Penyusunan ini juga berfungsi untuk meniriskan ikan sebelum diasap. Ikan yang sudah disusun pada para-para dimasukkan pada tungku pengasapan. Proses pengasapan dilakukan selama 8 jam, 9 jam dan 10 jam dengan jenis kayu yang berbeda. Ikan asap yang dihasilkan kemudian didinginkan dengan cara diangin-anginkan. Pendinginan dilakukan untuk mencegah kelembaban di dalam kemasan, dan untuk menghindari pertumbuhan mikroorganisme seperti bakteri dan kapang. Proses pengolahan ikan asap dapat dilihat pada Gambar 1 .

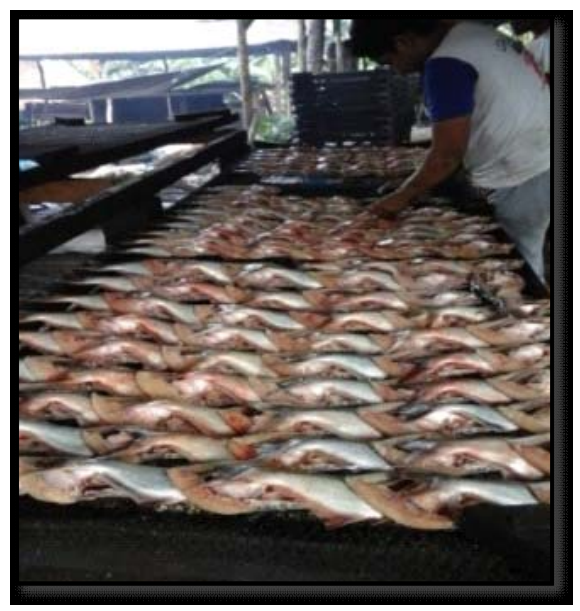

(a)

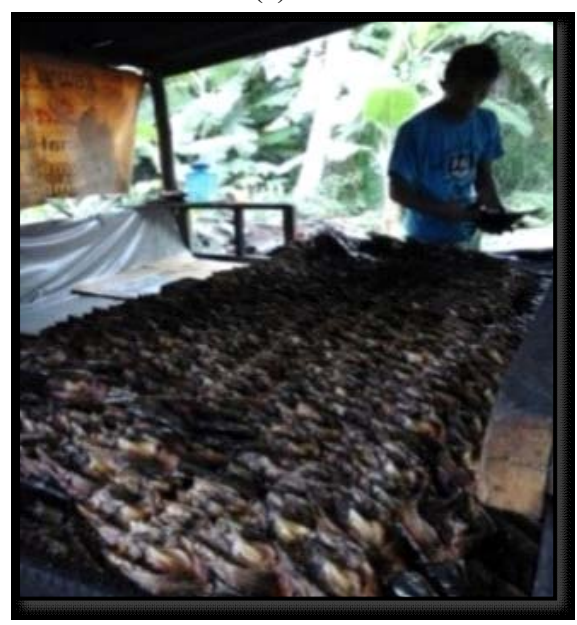

(c)

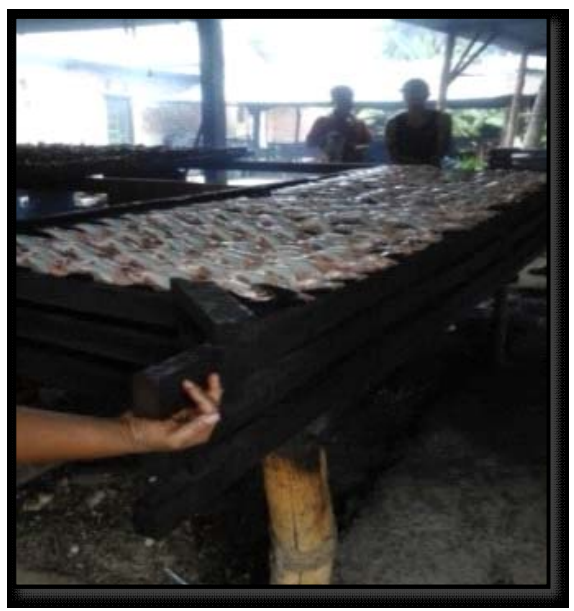

(b)

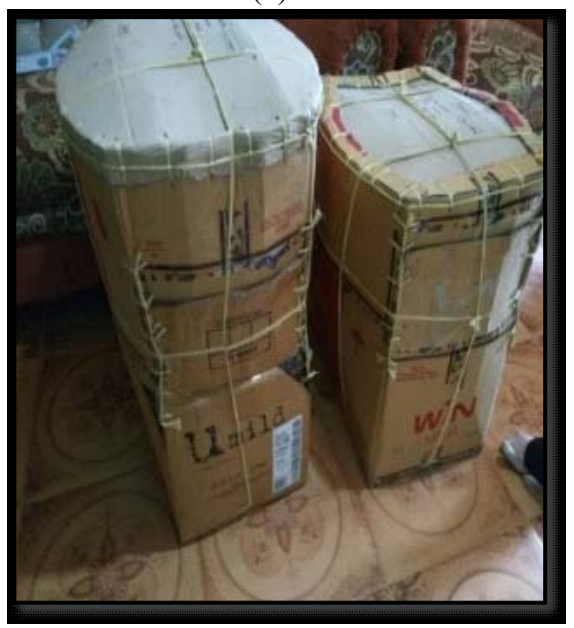

(d)

Gambar 1. (a) Penyusunan ikan dalam para-para, (b) proses pengasapan, (c) pendinginan, (d) pengepakan. Figure 1. (a) Layering of fish on "Para para", (b) Smoking process, (c) Cooling, (d) Packaging. 


\section{Pengujian hedonik ikan asap}

Uji hedonik (uji kesukaan) merupakan pengujian sensori yang dilakukan untuk menentukan tingkat penerimaan panelis terhadap suatu produk. Penelitian ini dilakukan untuk melihat ikan asap yang paling disukai oleh konsumen dari semua perlakuan. Nilai kesukaan ikan asap pada semua perlakuan dapat dilihat pada Tabel 1.

Tabel 1. Nilai hedonik ikan asap

Table 1. Hedonic value of smoked fish

\begin{tabular}{lccccc}
\hline Kode sampel & Kenampakan & Bau & Rasa & Tekstur & $\begin{array}{c}\text { Nilai } \\
\text { kesukaan }\end{array}$ \\
\hline KR8 & 5,9 & 6,0 & 5,7 & 5,2 & 5,7 \\
KR9 & 7,3 & 7,0 & 7,1 & 7,2 & 7,2 \\
KR10 & 6,7 & 6,9 & 6,2 & 6,2 & 6,5 \\
KK8 & 5,3 & 5,8 & 5,8 & 5,8 & 5,7 \\
KK9 & 6,1 & 6,0 & 6,2 & 6,2 & 6,1 \\
KK10 & 5,4 & 5,9 & 5,8 & 6,0 & 5,8 \\
\hline
\end{tabular}

Keterangan: KR8 = kayu rambutan dengan waktu pengasapan 8 jam, KR9 = kayu rambutan dengan waktu pengasapan 9 jam, KR10 = kayu rambutan dengan waktu pengasapan $10 \mathrm{jam}$, KK8 = Kayu karet dengan waktu pengasapan 8 jam, KK9= Kayu karet dengan waktu pengasapan 9 jam, KR10 = Kayu karet dengan waktu pengasapan 10 jam

\section{Kenampakan}

Karakteristik pertama yang dinilai oleh panelis pada suatu produk perikanan adalah nilai kenampakan. Kenampakan merupakan parameter dengan penilaian indra penglihatan yang meliputi keutuhan, warna, dan tampilan suatu makanan. Berdasarkan nilai rata-rata uji hedonik pada parameter kenampakan diketahui bahwa produk ikan patin asap yang disukai panelis adalah produk KR9 (pengasapan 9 jam dengan kayu rambutan). Kenampakan ikan asap yang diasap selama 9 jam dengan kayu rambutan lebih disukai karena warna yang dihasilkan lebih kecoklatan, mengkilap, utuh, dan terlihat kering. Moeljianto (1992) menyatakan bahwa warna ideal dari ikan hasil proses pengasapan adalah warna kuning emas kecoklatan. Warna emas kecoklatan pada ikan asap disebabkan karena reaksi kimia antara fenol dengan udara (Sulistijowati et al., 2011). Warna mengkilat disebabkan timbulnya reaksi kimia dari senyawa yang terdapat dalam ikan asap, yaitu formaldehid dengan fenol yang menghasilkan lapisan damar tiruan pada permukaan kulit ikan, sehingga menjadi mengkilat. Berlangsungnya reaksi ini memerlukan suasana asam, di mana asam ini telah tersedia dalam kandungan asap yang dihasilkan (Sulistijowati et al., 2011). Perbedaan nilai kenampakan pada ikan patin asap diduga akibat adanya reaksi komponen asap karbonil dengan protein yang mengandung asam amino yang terdapat dalam daging ikan yang menyebabkan ikan asap menjadi coklat kekuningan. Hal ini sesuai dengan pendapat Ruiter (1979) yang menyatakan bahwa karbonil mempunyai efek terbesar terhadap terjadinya pembentukan warna coklat pada produk asapan. Ikan asap dengan kayu karet pada semua perlakuan waktu tidak diminati oleh panelis karena memiliki kenampakan yang sedikit lebih gelap. Hal ini kemungkinan karena kayu karet mempunyai kandungan total asam yang tinggi dan kandungan senyawa phenol yang rendah (Towaha et al., 2013).

\section{Bau}

Bau atau aroma merupakan hal yang menentukan enak atau tidaknya suatu makanan. Hal-hal yang dinilai dalam uji bau difokuskan pada spesifik atau tidaknya aroma pada produk.

Nilai parameter bau tertinggi (nilai 7) adalah pada perlakuan pengasapan selama 9 jam dengan kayu rambutan. Ikan patin yang diasap dengan dengan kayu rambutan lebih disukai karena bau khas ikan asap masih terasa, sedangkan ikan asap dengan kayu karet memiliki aroma asap yang terlalu kuat, sehingga tidak disukai oleh panelis. Asap yang dihasilkan dari proses pembakaran akan menghasilkan senyawa fenol, yang akan mempengaruhi bau dari ikan asap yang dihasilkan (Ghazali et al., 2014).

Menurut Sulistijowati et al. (2011), fenol merupakan senyawa yang dihasilkan dari proses pengasapan yang membentuk aroma asap yang khas. Senyawa aromatik yang terkandung dalam asap sangat mempengaruhi bau ikan asap. Lebih lanjut Adawyah (2007) menyatakan bahwa pada pembakaran yang tidak sempurna, asap yang mengandung bahan organik akan bereaksi dengan ikan dan menghasilkan aroma asap. Menurut Utomo et al. (2012), kayu keras merupakan jenis kayu yang paling umum digunakan karena menghasilkan aroma lebih baik daripada kayu lunak atau bergetah.

\section{Rasa}

Rasa merupakan parameter yang menentukan disukai atau tidaknya suatu makanan. Penilaian rasa 
dapat berupa gurih atau tidaknya suatu produk yang dinilai. Nilai parameter rasa menunjukkan bahwa panelis lebih menyukai ikan dengan pengasapan selama 9 jam, menggunakan kayu rambutan. Asap yang diserap oleh daging ikan sangat bervariasi sesuai dengan lama waktu pengasapan, yang menyebabkan rasa pada ikan asap juga berbeda. Warna, rasa dan aroma ikan asap tergantung pada komponen yang dihasilkan melalui pembakaran, dalam hal ini tergantung pada jenis kayu yang digunakan. Karena cita rasa pada ikan asap dihasilkan oleh senyawa asam, fenol, aldehid yang terdapat pada asap (Sulistijowati et al., 2011). Fenol merupakan senyawa utama pembentuk aroma asap yang khas. Komponen fenol pada ikan asap berperan sebagai flavor bakteriostatik dan antioksidan (Swastawati et al., 2014).

Jenis-jenis kayu yang banyak mengandung resin atau damar kurang baik untuk pengasapan karena menghasilkan rasa pahit pada ikan (Suprayitno, 2017). Lebih lanjut Lawrie (2003) menjelaskan bahwa rasa yang diberikan oleh asap bervariasi. Asap yang sama dapat menghasilkan rasa yang berbeda disebabkan perbedaan lemak yang terkandung pada daging. Oleh karena itu, rasa produk daging asap sedikit banyaknya tergantung pada reaksi antara komponen asap dan protein daging. Utomo et al. (2012) menyatakan kayu keras merupakan jenis kayu yang paling umum digunakan untuk pengasapan karena menghasilkan aroma lebih baik daripada kayu lunak atau bergetah.

\section{Tekstur}

Tekstur berhubungan dengan rabaan atau sentuhan. Penilaian tekstur merupakan penilaian yang menggambarkan tingkat kepadatan, kekeringan, dan kekompakan pada produk yang dinilai. Nilai parameter tekstur menunjukkan bahwa panelis lebih menyukai ikan yang diasapi dengan kayu rambutan selama 9 jam, dengan nilai rata-rata 7,2 (suka). Tekstur ikan asap yang dihasilkan adalah padat, kering dan tidak keras. Sedangkan pada sampel 8 jam pengasapan tekstur yang dihasilkan lebih lunak, dan belum kering secara keseluruhan. Semakin lama waktu pengasapan akan dihasilkan ikan asap dengan tekstur yang lebih padat dan kompak (sesuai spesifikasi ikan asap). Menurut Poernomo (2004), banyak hal yang mempengaruhi tekstur antara lain rasio kandungan protein, lemak, suhu pengolahan, kadar air dan aktivitas air. Lebih lanjut Failinsur (2012) menjelaskan bahwa ikan yang memiliki kandungan lemak yang tinggi akan menghambat proses penguapan air sehingga teksturnya menjadi lunak, lembab dan lebih mengkilap jika dibandingkan dengan ikan yang memiliki kadar lemak yang rendah akan menghasilkan tekstur yang kering, keras dan tidak mengkilap. Proses pengasapan panas juga menyebabkan tekstur ikan patin asap lebih elastis, kompak dan tidak keras.

Grafik laba-laba nilai kesukaan panelis terhadap ikan asap dapat dilihat pada Gambar 2.

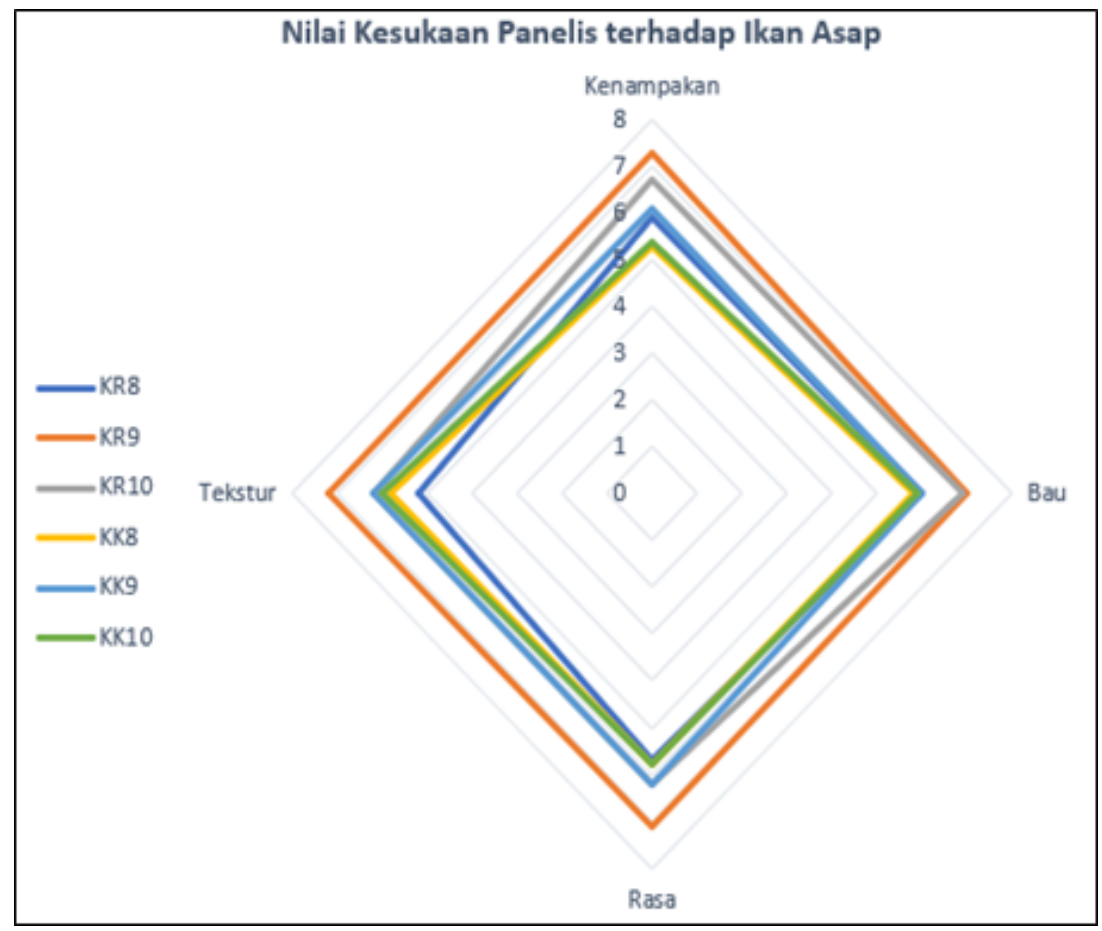

Gambar 2. Grafik nilai rata-rata hedonik Ikan Asap.

Figure 2. Hedonic Graph of smoked fish. 


\section{Pengaruh perbedaan jenis kayu dan lama pengasapan terhadap kesukaan panelis}

Pengaruh perbedaan jenis kayu dan lama pengasapan terhadap kesukaan panelis diuji dengan analisis non parametrik Kruskal Wallis. Menurut Kadir (2015), Uji Kruskal Wallis digunakan sebagai pengganti uji ANOVA satu jalan apabila data yang akan diuji berbentuk data peringkat atau data dalam skala ordinal. Hasil analisis statistik pada pengaruh jenis kayu terhadap kesukaan (hedonik) menunjukkan bahwa Chi Square $=3,627$ dan $p$-value $0,057>0,05$. Hal ini berarti nilai hedonik ikan patin asap yang diasap dengan kayu karet maupun kayu rambutan adalah sama. Dengan demikian jenis kayu (kayu karet maupun kayu rambutan) tidak berpengaruh nyata terhadap nilai hedonik ikan patin asap. Hal ini diduga karena baik kayu karet maupun kayu rambutan merupakan jenis kayu keras yang samasama baik digunakan untuk pengasapan. Walaupun mutu dan volume asap yang dihasilkan tergantung pada jenis kayu yang digunakan dalam proses pengasapan (Sulistijowati et al., 2011), namun pada umumnya rasa pada ikan asap lebih dipengaruhi oleh kandungan protein dan lemak pada ikan, karena jenis kayu yang sama dapat menghasilkan rasa yang berbeda dengan perbedaan lemak pada daging (Lawrie, 2003). Kostyra et al. (2006) menyatakan senyawa karbonil dan fenol maupun turunannya berkontribusi dalam menentukan warna, rasa, dan aroma khas pada produk yang diasap.

Hasil analisis statistik pada pengaruh lama pengasapan terhadap kesukaan (hedonik) menunjukkan bahwa Chi Square = 7,506 dan p-value 0,023 < 0,05. Berarti nilai hedonik ikan patin asap yang diasap selama 8 jam, 9 jam dan 10 jam adalah berbeda. Dengan demikian lama pengasapan pada rentang waktu 8 jam, 9 jam dan 10 jam, berpengaruh nyata terhadap nilai hedonik ikan patin asap. Semakin lama waktu pengasapan, ikan patin yang dihasilkan semakin terlihat coklat, semakin mengkilat dan lebih kering. Namun, panelis memiliki batas nilai penerimaan terhadap waktu pengasapan yaitu 9 jam.

Hal ini tidak sesuai dengan Isamu et al. (2012), yang menyatakan bahwa semakin lama waktu pengasapan akan mengakibatkan jumlah komponen asap yang menempel pada ikan semakin banyak yang akan menghasilkan kenampakan, bau, rasa dan aroma yang lebih bagus. Pada pengasapan selama 10 jam, panelis semakin tidak menyukai ikan patin asap yang dihasilkan, karena memiliki kenampakan yang terlalu kecoklatan, rasa yang agak pahit serta aroma asap yang terlalu kuat.

\section{KESIMPULAN}

Ikan patin asap yang paling disukai oleh panelis adalah ikan patin yang dihasilkan dari proses pengasapan dengan kayu rambutan selama 9 jam. Berdasarkan uji statistik diketahui bahwa jenis kayu (kayu karet dan kayu rambutan) tidak berpengaruh terhadap nilai hedonik ikan patin asap, sedangkan lama pengasapan (8 jam, 9 jam, 10 jam) berpengaruh terhadap nilai hedonik ikan patin asap.

\section{DAFTAR PUSTAKA}

Adawyah, R. (2007). Pengolahan dan Pengawetan Ikan. Jakarta: Bumi Aksara.

Afrianto, E., \& Liviawaty, E. (1989). Pengawetan dan Pengolahan Ikan. Yogyakarta: Konisius.

Badan Standarisasi Nasional (BSN). (2013). Standar Nasional Indonesia (SNI 2725:2013), tentang Ikan Asap dengan Pengasapan Panas. Jakarta: DSN.

Ghazali, R.R., Swastawati, F., \& Ramadhon. (2014). Analisis tingkat keamanan ikan mayung (Arius thallasinus) asap yang diolah dengan metode pengasapan berbeda. UNDIP Semarang.

Failinsur. (2012). Pengaruh Metode Pemberian Bumbu dan Jenis Ikan Terhadap Mutu Sensori Pada Ikan Air Tawar Asap. Jurnal Litbang Industri, 2(2), 8796.

Hadinoto, S., Kolanus, J. P. M., Komers, R. W., \& Manduapessy. (2016). Karakteristik Mutu Ikan Cakalang (Katsuwonus Pelamis) Asap Menggunakan Asap Cair dari Tempurung Kelapa. Majalah BIAM 12 (01), 20-26.

Isamu, K. T., Hari, P., \& Sudarminto, S. Y. (2012). Karakteristik, Fisik, Kimia dan Organoleptik Ikan Cakalang (Katsuwonus Pelamis) Asap di Kendari. Jurnal Teknologi Pertanian, 13(2), 105-110.

Kadir. (2015). Statistika Terapan (Konsep, contoh dan analisisi data dengan program SPSS/Lisrel dalam Penelitian). Jakarta: Rajawali Pers.

Kerlinger, F. (1986). Foundations of Behavioral Research (2nd Edition). Holt, Rinehart and Winston.

Kostyra, E., Pikielna, \& Barylko, N. (2006). Volatiles Composition and Flavour Profile Identity of Smoke Flavourings.

Lambongadil, G. P., Reo, A. R., \& Onibala, H. (2013). Studi Mutu Produk Ikan Japuh (Dussumieria acuta C.V.) Asap Kering Industri Rumah Tangga di Desa Tumpaan Baru Kecamatan Tumpaan. Fakultas Perikanan dan Ilmu Kelautan. Universitas Samratulangi. Sulawesi Utara. Manado. Jurnal Media Teknologi Hasil Perikanan, 1(2), 12-18. 
Lawrie, R.A. (2003). Ilmu Daging. Penerjemah. Jakarta: Universitas Indonesia. Terjemahan dari: Meat Science.

Leroi, \& Joffraud, J. J. (2000). Salt and smoke simultaneously effect chemical and sensory quality of cold-smoked salmon during $5{ }^{\circ} \mathrm{C}$ storage predicted using factorial design. Journal of Food Protection, 63, 1222-1227.

Mardiana, N., Waluyo, S., \& Ali, M. (2014). Analisis kualitas ikan sembilang (Paraplotosus albilabris) asap di kelompok pengolahan ikan Mina Mulya, Kecamatan Pasir Sakti Lampung Timur. Jurnal Teknik Pertanian Lampung, 3(3), 283-290.

Muchtadi, T. R., \& Sugiono. (1992). Ilmu Pengetahuan Bahan Pangan. Departemen Pendidikan dan Kebudayaan. Direktorat Jenderal Tinggi Pusat Antar Universitas Pangan dan Gizi. Bogor: Institut Pertanian Bogor.

Poernomo, S. H. (2004). Teknologi Pengolahan Ikan. Jakarta: Departemen Kelautan dan Perikanan pusat pendidikan dan pelatihan perikanan.

Ratna, Safrida, \& Yulinar. (2011). Variasi Jenis Bahan Bakar pada Pengasapan Ikan Bandeng (ChanosChanos Forskal) Menggunakan Alat Pengasapan Tipe Kabinet. Jurnal Ilmiah Pendidikan Biologi, Biologi Edukasi, 3(2), 34-37.

Rorvik, L. M. (2000). Listeria monocytogenes in the smoked salmon industry. International Journal of Food Microbiology, 62, 183-190.
Ruiter, A. (1979). Color of Smoked Foods. J Food Technology, 54-63.

Sulistijowati, R., Djunaedi, O. S., Nurhajati, J., Afrianto, E., \& Udin, Z. (2011). Mekanisme Pengasapan Ikan. Jakarta: UNPAD press.

Suprayitno, E. (2017). Dasar Pengawetan. Jakarta: UB press.

Suroso, E., Utomo, T. P., Hidayati, S., \& Nuraini, A. (2018). Pengasapan Ikan Kembung Menggunakan Asap Cair dari Kayu Karet Hasil Redestilasi. Jurnal Pengolahan Hasil Perikanan Indonesia, 21(1), 4253.

Swastawati, F., Darmanto, Y. S., Sya'rani, L., Rahayu, K., \& Taylor, A. (2014). Quality characteristic of smoked skipjack (Katsuwonus pelamis) using different liquid smoke. International Journal of Bioscience, Biochemistry and Bioinformatics, 4(2), $94-99$.

Towaha, J., Aunillah, A., \& Purwanto E. H. (2013). Pemanfaatan asap cair kayu karet dan tempurung kelapa untuk penanganan polusi udara pada lump. Buletin RISTRI, 4(1), 71-80.

Utomo, B. S. B., Wibowo, S., \& Widianto., T. N. (2012). Asap Cair. Jakarta: Penebar Swadaya.

Wibowo, S. (2002). Industri Pengasapan Ikan. Yogyakarta: Penebar Swadaya. 
Pengaruh perbedaan jenis kayu bakar dan lama pengasapsan.... (Resmi Siregar) 